\title{
WHO and industry combine to form ethics body
}

The World Health Organization (WHO) is joining forces with the pharmaceutical industry to create a new body charged with helping developing countries to provide ethical review of clinical trials. So prominent is industry's role in the new effort that its creation was expected to be formally announced at the Drug Information Association conference in Chicago last month.

The new body, known as Strategic Initiative for Developing Capacity in Ethical Review (SIDCER), has the brief of responding

to increas-

ing demands for strict ethical oversight of trials without unnecessarily delaying such trials or increasing their costs. It will operate primarily by coordinating the activities of a number of

\begin{tabular}{|c|c|c|}
\hline Geographic area & Amount (US \$ mil.) & Share $(\%)^{1}$ \\
\hline Canada & 451.2 & 9.2 \\
\hline Latin America (inc. all C iribbean nations) & 78.5 & 1.6 \\
\hline $\begin{array}{l}\text { Western Europe (EC, European Free } \\
\text { Trade Association and Switzerland) }\end{array}$ & $3,569.2$ & 72.9 \\
\hline Central and Eastern Europe (inc. əx-USSR) & 21.6 & 0.44 \\
\hline Middle East (inc. Turkey) & 3.5 & 0.07 \\
\hline Africa & 4.1 & 0.08 \\
\hline $\begin{array}{l}\text { Asia/Pacific (from Pakistan to SE Asia } \\
\text { inc. China, Taiwan, and the Koreas }\end{array}$ & 19.7 & 0.40 \\
\hline Japan & 711.1 & 14.5 \\
\hline Australia and New Zealand & $45.4=18$ & 0.93 \\
\hline Total & $4,904.2$ & \\
\hline
\end{tabular}

${ }^{1}$ Percentages do not add up to 100 because of rounding based on the FERCAP model in Africa (the Pan-African Bioethics Initiative), and Mexico (Latin American Ethics Committees in Health Research). "These regional forums have been very effective, but some have had difficulty in raising funds for their work, and this is one of the ways that SIDCER can help, by raising funds centrally that are then distributed to the fora to carry out their activities," says Crawley.

Much of this funding will continue to come from public bodies such as TDR. At the same time, SIDCER hopes to attract money from the pharmaceutical industry through its trade organization, the International Federation of Pharmaceutical Manufacturers Associations (IFPMA). Answering those critical of industrial sponsorship, Crawley points regional forums that have been created in recent years to assist governments in building up their ethical review capacity.

"Ethics has become both a guardian of and a gateway to research, in the sense that ethical review is one of the doorways that research has to pass through before it can be carried out in a country," says SIDCER's Francis Crawley. "Most research institutions won't go anywhere that there is not a strong sense of ethics."

Hitherto, plans for providing some form of central coordination for ethical review committees in developing countries have been under development within WHO's Tropical Disease Research (TDR) department. Following a TDR workshop in Thailand in 1999, a Forum for Ethical Review Committees in Asia and the Western Pacific (FERCAP) was created. FERCAP is based in Thailand with representatives in the Philippines, India and Indonesia. Similar forums have been established
Dutch biotechnology company, Crucell, is to collaborate with the US National Institute of Allergy and Infectious Diseases (NIAID) to develop the first vaccine against the Ebola virus. Although Ebola kills far fewer people worldwide than scourges like malaria and AIDS, new concerns about bioterrorism-and the possibility that Ebola could eventually blossom into a global pandemic-have inspired a new effort to develop vaccines.

Live Ebola virus must be handled in a high-level 'P4' containment laboratory,

than from individual companies, as this will reduce the likelihood that it is seen to be promoting the interests of a particular corporation. "There is no way that one company can have an impact on what we do," he insists. IFPMA officials also argue that it is in the interests of the industry as a whole to secure a greater international recognition of the ethical reviews carried out in individual countries, as this would make it easier to persuade regulatory bodies in one country to accept the results of trials carried out in another.

Although there is currently no central database cataloguing research conducted in developing countries, the US Food and Drug Administration (FDA) has recorded a 16-fold increase over the last decade in the number of foreign clinical investigators conducting research into new medicines. The largest growth in trials has occurred in Eastern European countries and Latin America (see Table).

The FDA's parent organization, the Department of Health and Human Services admits, "FDA receives minimal information on the performance of foreign institutional review boards. It does not inspect these boards, nor does it tend to receive much information from the host countries of these boards. It cannot necessarily depend on foreign investigators signing attestations that they will uphold human subject protections." Recommendations for change were outlined in its September 2001 report, The Globalization of Clinical Trials (http://oig.hhs.gov/oei/reports/oei-01-0000190.pdf).

David Dickson, London

\section{Ebola vaccine gets corporate backer}

and the virus does not seem susceptible to a straightforward vaccination strategy. The new vaccine, which was developed at NIAID, uses DNA encoding three Ebola glycoproteins and one nucleoprotein, followed by a boost with a replication-defective adenovirus expressing Ebola antigens (Nature 408, 605; 2000). It is the first vaccine to generate protective immunity against Ebola in non-human primates.

Gary Nabel, director of the Vaccine Research Center at NIAID and senior researcher on the project, says, "DNA is 